\title{
FcMgv1, FcStuA AND FcVeA BASED GENETIC CHARACTERIZATION IN Fusarium culmorum (W.G. Smith)
}

\author{
Emre YÖRÜK*, Özlem SEFER
}

İstanbul Yeni Yüzyil University, Faculty of Arts and Sciences, Department of Molecular Biology and Genetics, Istanbul, TURKEY

*Corresponding author: e-mail: emreyoruk@ outlook.com

Cite this article as:

Yörük E. \& Sefer Ö. 2018. FcMgv1, FcStuA and FcVeA Based Genetic Characterization in Fusarium culmorum (W.G. Smith). Trakya Univ J Nat Sci, 19(1): 63-69, DOI: 10.23902/trkjnat.334792

Received: 15 August 2017, Accepted: 21 March 2018, Online First: 24 March 2018, Published: 15 April 2018

\begin{abstract}
Fusarium culmorum (W.G. Smith) leads to economic losses in wheat and barley fields in Turkey as well as in many countries worldwide as a result of head blight and crown rot diseases. In this study, in vitro growth capacity of 33 F. culmorum isolates originating from Turkey and the relationship between phenotypic and genetic characteristics obtained based on similarities of $F c M g v l, F c S t u A$ and $F c V e A$ genes were investigated. Linear growth rate values were recorded at $4^{\text {th }}$ and $7^{\text {th }}$ days of incubation. The mean linear growth rate values ranged from $7.58 \pm 1.06$ to $14.7 \pm 1.26 \mathrm{~mm} /$ day. The isolates $\mathrm{F} 2$ and $18 \mathrm{~F}$ with relatively high linear growth values and the isolates $12 \mathrm{~F}$ and F19 with relatively low linear growth values, were selected to be used in multiloci based genotyping analysis. FcMgvl, FcStuA and FcVeA genes were amplified in lengths of 1733, 2001 and $1898 \mathrm{bp}$, respectively. The genes were sequenced, aligned and then subjected to BLASTn and to maximum likelihood topology analysis. Nucleotide sequence of each gene showed maximum hit with associated genes deposited in NCBI with 0.0-0.0 Evalues and 1188 to 3256 bit scores. Alignment analysis resulted in at least $89 \%$ bootstrap support. Moreover, isolates with similar linear growth rates were co-clustered in phylogenetic analysis. The findings obtained in this study showed that the three genes which are essential for fungal survival could be used in genetic characterization analysis and in revealing the associations between their genetic and phenotypic characteristics.
\end{abstract}

Key words: Fusarium culmorum, PCR, genetic characterization, genetic diversity, linear growth rate.

Özet: Dünya çapında pek çok ülkede olduğu gibi Türkiye'de de Fusarium culmorum (W.G. Smith) başak yanıklığı ve kök çürüklüğü hastalıkları ile arpa ve buğday tarım alanlarında ekonomik kayıplara yol açar. Bu çalıșmada, Türkiye'den köken alan $33 F$. culmorum izolatının in vitro büyüme kapasitesi ile $F c M g v 1, F c S t u A$ ve $F c V e A$ genetik benzerliği aracılığı ile elde edilen fenotipik ve genetik karakterlerin ilişkisi incelenmiştir. Doğrusal büyüme oranı değerleri inkübasyonun 4. ve 7. günlerinde

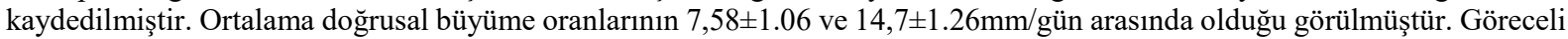
olarak yüksek LGR değerlerine sahip olduğu belirlenen F2 ile 18F izolatları ile göreceli olarak düşük LGR değerlerine sahip olduğu belirlenen $12 \mathrm{~F}$ ve F19 izolatları multilokus temelli genotiplendirme analizlerinde kullanılmak üzere seçilmiştir. FcMgvl, FcStuA ve FcVeA genlerine ait sırasıyla 1733, 2001 ve 1898 bç ürünler elde edilmiştir. Genler dizilenmiş, bir araya getirilmiş ve BLASTn ile maksimum olasılık topoloji analizi yapılmıştır. Her bir genin nükleotid dizisi NCBI'da 0,0-0,0 Edeğeri ve 1188-3256 arası bit skoru vermiştir. Hizalama analizi en az \%89 ön yükleme değeri ile sonuçlanmıştır. Ayrıca, benzer büyüme oranına sahip izolatlar filogenetik analizlerde aynı alt kümede yer almıştır. Bu çalışmada elde edilen bulgular, fungal yaşam için gerekli olan bu üç genin, genetik karakterizasyonda ve fenotipik ve genotipik özellikleri arasında ilişki kurulmasında kullanılabileceğini ortaya konmuştur.

\section{Introduction}

Fusarium culmorum (W.G. Smith) has been reported to be associated with head blight, ear blight and crown rot, diseases of cereals including wheat, barley, and maize (Miedaner et al. 2008). This fungus is the second major causal agent of head blight, one of the most destructive diseases affecting cereals worldwide and it is a predominating agent particularly in cooler regions of the world (Yli-Mattila et al. 2013, Pasquali \& Migheli 2014, Yörük et al. 2016). F. culmorum is known as a quarantined phytopathogen and it is capable of producing some major and minor mycotoxins such as trichothecenes, zearalenon, fusarin $\mathrm{C}$, and butanolide. In addition to its hazardous effects on cereals, $F$. culmorum also have adverse effects on human and animal health (e.g. carcinogenic and estrogenic effects) especially through class B trichothecenes and zearalenone (Desjardins \& Proctor 2007, Niessen 2007). Therefore, detailed characterization of $F$. culmorum isolates is a requisite in studies considering fight against diseases associated with F. culmorum.

The necrotrophic $F$. culmorum is an asexually reproducing fungal plant pathogen, lacking a sexual stage. 
However, potential parasexual reproduction is also assumed for $F$. culmorum since two mating types, MAT11 and $M A T 1-2$, were reported to be present approximately in equal proportions (Obanor et al. 2010, Albayrak et al. 2016). The number of chromosomal nucleotide sequence data of $F$. culmorum has recently increased by registrations of growing sequence data in GenBank and some other databases. However, the number of annotated and well characterized $F$. culmorum genes is still limited. Since the species has a high level of genetic variation worldwide (Miedaner et al. 2008), detailed and comprehensive genetic and genomic characterization of isolates are crucial in terms of effective control of the fungus. Several different polymerase chain reaction (PCR) based strategies including single primer based genotyping, sequencing based locus screening, and restriction endonuclease digestion based genotyping have been used in $F$. culmorum genotyping. SCAR-RAPDPCR (Sequence characterized amplified region-random amplified polymorphic DNA-polymerase chain reaction), inter simple sequence repeat (ISSR), microsatellite PCR, restriction fragment length polymorphisms (RFLP), and single locus genotyping are the most common methods used in F. culmorum identification studies. SCAR and AFLP (Amplified fragment length polymorphism) are less frequently used in genotyping studies (Nicholson et al. 1998, Miedaner et al. 2001, Mishra et al. 2003, Chung et al. 2008, Albayrak et al. 2016). These techniques are generally cost effective, non-laborious, and not timeconsuming and they do not need high amount of DNA but minimum prior nucleotide sequence knowledge. On the other hand, non-reproducible bands and inconsistent findings are the two major disadvantages of these techniques. In addition, a majority of these marker techniques do not provide co-dominant markers meaning that there is no possibility to distinguish the heterozygote individuals from the homozygote one (Williams et al. 1990, Bornet \& Branchard 2001, Llorens et al. 2006).

Multilocus genotyping methods are promising in terms of providing a fast, cost effective, reliable, and reproducible strategy for $F$. culmorum genotyping. The most commonly used strategy in Fusarium spp. studies is the multiloci genotyping applied for distinguishing of $F$. graminearum (Schwabe) species complex members via 12 different genes of approximately 16kb (O'Donnell et al. 2000, Yli-Mattila et al. 2009, Sarver et al. 2011). In contrast to its efficient use in species complex differentiation of $F$. graminearum, this strategy is not useful for $F$. culmorum which was reported as a monophyletic species (Obanor et al. 2010, Przemieniecki et al. 2014). The use of multiloci genotyping analysis led so far to precise investigation of even if not all phenotypic characteristics and genotypic similarities and to well recognition of geographic region and genotypic diversity associations. Multiloci genotyping analysis showed that $F$. graminearum could be defined as a species complex with 15 different members (van der Lee et al. 2015, Pasquali et al. 2016). Despite the relatively long nucleotide sequence regions that have been used in multiloci genotyping, a low level of genetic diversity was detected. However, because presence of high level of intra-specific variation could not be detected by multiloci genotyping via 12 genes, novel strategies can be adapted to Fusarium spp. characterization. These novel strategies could be useful in making associations with genetic similarities and some other phenotypic characteristics such as host species, chemotype etc. in Fusarium isolates. Yörük \& Sefer (2017) used a genotyping strategy based on sequencing of $\mathrm{FgMg \nu l}, \mathrm{FgStuA}$, and $\mathrm{FgVeA}$ genes in $F$. graminearum to make association between some characteristics such as 15-acetyldeoxynivalenol producing capacity, radial growth capacity, and genetic similarity. The findings obtained from $F g M g v 1, F g S t u A$ and $F g V e A$ sequencing and alignment assays showed that genotyping of these genes could be useful in detailed differentiation of fungal species complex members. Since FgMgvl, FgStuA and FgVeA genes whose expressions are essential in sexual/asexual development, cell wall formation and survival of fungal cells possess high level of genetic similarity in terms of nucleotide sequence data, variation in these genes can lead to significant differences in phenotypic characteristics (Hou et al. 2002, Jiang et al. 2011, Pasquali et al. 2013). Macroconidia and/or microconidia production, radial growth rate, host type, and chemotype characteristics can be potential phenotypic traits that can be associated with nucleotide sequence variation. In this study, it was aimed to develop novel multiloci genotyping by amplification and sequencing of FcMgv1, FcVeA, and FcStuA genes and to make association between genetic diversity and phenotypic characteristics.

\section{Materials and Methods}

Fungal materials and linear growth rate (LGR) assays

Fusarium culmorum isolates were provided by Dr. Berna Tunali from Ondokuz Mayis University, Agricultural Faculty, Department of Plant Protection. Each of the 33 isolates (see Table 1) included in the study was given a specific code, purified and identified according to standard morphological and genetic methods (Yörük et al. 2016).

Czapek dox agar (CDA) medium was used for in vitro growth of the isolates. Fresh F. culmorum cultures were initiated by placing the mycelia plug in the middle of the $\mathrm{CDA}$ medium. The cultures were incubated at $25^{\circ} \mathrm{C}$ for 7 days. Linear growth rates (LGR) were calculated as $\mathrm{mm} /$ day at $4^{\text {th }}$ and $7^{\text {th }}$ days of incubation (Irzykowska $e t$ al. 2013). Mean and standard derivation values for LGR data were calculated using column statistics (Graphpad Prism 5.0 software, USA).

\section{Genomic DNA extraction}

Genomic DNA (gDNA) of the isolates was isolated from 7-day-old cultures using the CTAB-based DNA isolation kit (BioBasic, Canada). Approximately 100mg of mycelium on the culture surface was collected and after washing with $96 \%$ ethanol for 3 minutes, mycelium was homogenized in liquid nitrogen with sterile mortar and 
pestle. The homogenate was transferred to a microtube and the binding, washing and elution steps were carried out according to manufacturer's recommendations. The purities and quantities of gDNA was analysed via spectrophotometer (Thermo, USA) and 1\% agarose gel electrophoresis. gDNA was visualized under UV light of gel documentation system (Maestrogen, Taiwan) by staining with $0.2 \mu \mathrm{g} / \mathrm{mL}$ ethidium bromide. Electrophoresis was carried out under $60 \mathrm{~V}$ constant power for 60 minutes.

Table 1. Codes, host plants, the region of isolations, the mating types and the isolation years of the $F$. culmorum isolates.

\begin{tabular}{|c|c|c|c|c|}
\hline Code & Host & Region/Province & Mating & Year \\
\hline F1 & Wheat & Marmara & MAT1-1 & 2006 \\
\hline $\mathrm{F} 2$ & Wheat & Marmara & MAT1-2 & 2006 \\
\hline F3 & Wheat & Konya & MAT1-2 & 2006 \\
\hline $\mathrm{F} 4$ & Wheat & Marmara & MAT1-2 & 2006 \\
\hline F10 & Wheat & Bilecik & MAT1-1 & 2006 \\
\hline F12 & Wheat & Balıkesir & MAT1-2 & 2006 \\
\hline F14 & Wheat & Bilecik & MAT1-2 & 2006 \\
\hline F15 & Wheat & Sinop & MAT1-1 & 2006 \\
\hline F16 & Wheat & Konya & MAT1-1 & 2006 \\
\hline $\mathrm{F} 17$ & Wheat & Konya & MAT1-1 & 2006 \\
\hline F19 & Wheat & Konya & MAT1-1 & 2006 \\
\hline $\mathrm{F} 20$ & Wheat & Bilecik & MAT1-2 & 2006 \\
\hline $\mathrm{F} 21$ & Wheat & Uşak & MAT1-1 & 2006 \\
\hline F24 & Wheat & Konya & $M A T 1-2$ & 2006 \\
\hline $8 \mathrm{~F}$ & Wheat & Ankara & $M A T 1-2$ & 2009 \\
\hline $9 \mathrm{~F}$ & Wheat & Isparta & MAT1-1 & 2008 \\
\hline $10 \mathrm{~F}$ & Wheat & Samsun & MAT1-2 & 2007 \\
\hline $11 \mathrm{~F}$ & Wheat & Corum & $M A T 1-2$ & 2009 \\
\hline $12 \mathrm{~F}$ & Wheat & Amasya & $M A T 1-2$ & 2009 \\
\hline $13 \mathrm{~F}$ & Wheat & Konya & MAT1-1 & 2008 \\
\hline $17 \mathrm{~F}$ & Wheat & Ankara & MAT1-1/2 & 2009 \\
\hline $18 \mathrm{~F}$ & Wheat & Eskiş̧ehir & MAT1-1/2 & 2010 \\
\hline $19 \mathrm{~F}$ & Wheat & Eskişehir & MAT1-1/2 & 2010 \\
\hline $20 \mathrm{~F}$ & Barley & Afyon & MAT1-1 & 2011 \\
\hline 14-1TR & Barley & Sivas & MAT1-2 & 2014 \\
\hline 14-2TR & Wheat & Samsun & MAT1-1 & 2014 \\
\hline 15-1TR & Wheat & Tekirdağ & $M A T 1-1 / 2$ & 2015 \\
\hline 14-3TR & Wheat & Yozgat & MAT1-1/2 & 2014 \\
\hline 09-1TR & Wheat & Kastamonu & $M A T 1-1 / 2$ & 2009 \\
\hline $15-2 \mathrm{TR}$ & Wheat & Edirne & MAT1-2 & 2015 \\
\hline 15-3TR & Barley & Tekirdağ & MAT1-2 & 2015 \\
\hline $15-4 \mathrm{TR}$ & Wheat & Edirne & MAT1-1/2 & 2015 \\
\hline 14-8TR & Wheat & Amasya & MAT1-2 & 2014 \\
\hline
\end{tabular}

FcMgv1, FcStuA and FcVeA amplification and cloning

Allele specific or chromosomal nucleotide sequence data of $F c M g v 1, F c S t u A$ and $F c V e A$ genes were obtained from the GenBank with accession numbers AF492766.1, HG970332.2 and HQ436464.1, respectively. The primers of 20 nucleotides in length were designed using the "Primer 3" software (Rozen \& Skaletsky 2000) for the polymerase chain reaction (PCR). PCRs were carried out in a reaction volume of $50 \mu \mathrm{L}$ including $1 \mathrm{X}$ PCR mix (Takara, Japan), 10pmol of each primer (Table 2), and 50ng of DNA. PCR amplification was performed by predenaturation at $98^{\circ} \mathrm{C}$ for $2 \mathrm{~min}$, followed by 34 cycles of amplification at $98^{\circ} \mathrm{C}$ for $30 \mathrm{~s}, 55^{\circ} \mathrm{C}$ for $30 \mathrm{~s}, 72^{\circ} \mathrm{C}$ for $3 \mathrm{~min}$ and final extension at $72^{\circ} \mathrm{C}$ for $5 \mathrm{~min}$. PCR bands were separated on $1.5 \%$ agarose gels. Qualitative analysis of bands was carried out via gel documentation system.

Table 2. Primers used in this study.

\begin{tabular}{ccc}
\hline \hline Primer name & Sequence 5'-3' & Amplicon Size \\
\hline \hline \multirow{2}{*}{ MGVSPANF } & ATGGGCGACCT & \\
& ACAAGGACG & 1733bp \\
MGVSPANR & TTATCTTCGAG & \\
& AAGCATCCA & \\
\hline \multirow{2}{*}{ STUASPANF } & ATGAACCAAA & \\
& GTCATCACCA & \multirow{2}{*}{ 2001bp } \\
STUASPANR & CTATCCAAAGG & \\
& ACTGTTGCC & \\
\hline \multirow{2}{*}{ VELVETSPANF } & CTGGGTTCCTC & \\
& TCTGCCTTA & 1898bp \\
VELVETSPANR & TGTCGCTCATG & \\
& TATCTTCCAT & \\
\hline \hline
\end{tabular}

PCR bands were purified from agarose gels by using a gel extraction kit (BioBasic, Canada). Pieces (100$200 \mathrm{mg}$ ) including amplicons were cut form the gels and the purification was carried out according to the protocol provided by the manufacturer.

\section{Bioinformatics assays}

The sequencing process was maintained based on Sanger dideoxy termination method using "DYEnamic ET Terminator Cycle Sequencing” kit (Amersham, USA) on ABI PRISM 310 system. The nucleotide sequence was displayed in chromatograms using the "Chromas Pro" software. The sequences translated to FASTA format were subjected to BLASTN analysis. The nucleotide sequences generated via forward and reverse primers were aligned via DNA Dragon software. Assembled DNA sequences were used in multiple alignment analysis via ClustalW 1.8. software and in neighbor joining (NJ) topology analysis via Mega 6.0 software (Tamura et al. 2013). Pairwise distance and bootstrap support values were recorded for each assay. Accession numbers for FgMgvl, FgStuA and FcVeA genes (see above) were used as reference control in alignment analysis. The potential amino acids changes were characterized in "HOPE amino acid mutation" analysis. 


\section{Results}

\section{LGR analysis and fungal sample selection}

Single spore $F$. culmorum isolates were grown successfully on CDA media with a main pigmentation of red to tan colour (data not shown). Each isolate was used in LGR assays. The minimum and maximum mean LGR values of the isolates were $7.58 \pm 1.06$ and $14.7 \pm 1.26 \mathrm{~mm} /$ day, respectively (Fig. 1). Isolates with relatively high (F2 and 18F) and low (12F and F19) LGR values were used in multilocus sequencing based genotyping analysis.

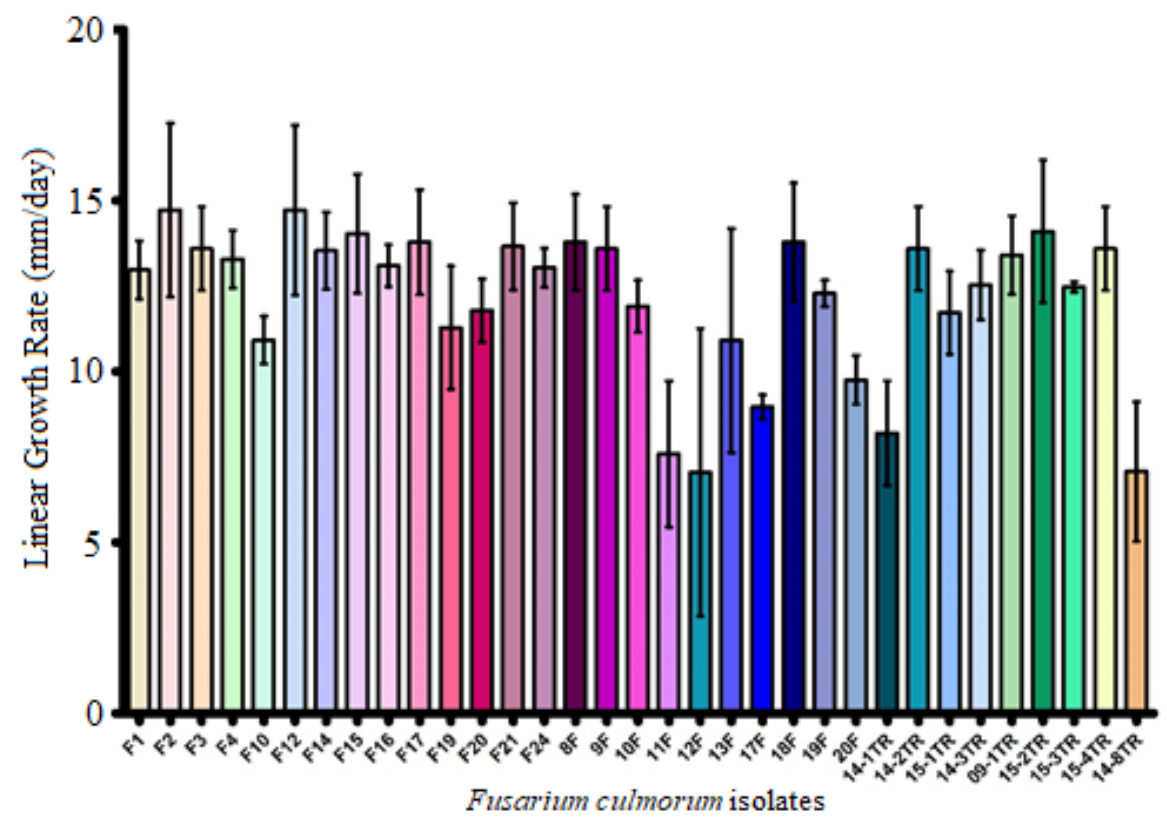

Fig. 1. LGR data of the F. culmorum isolates.

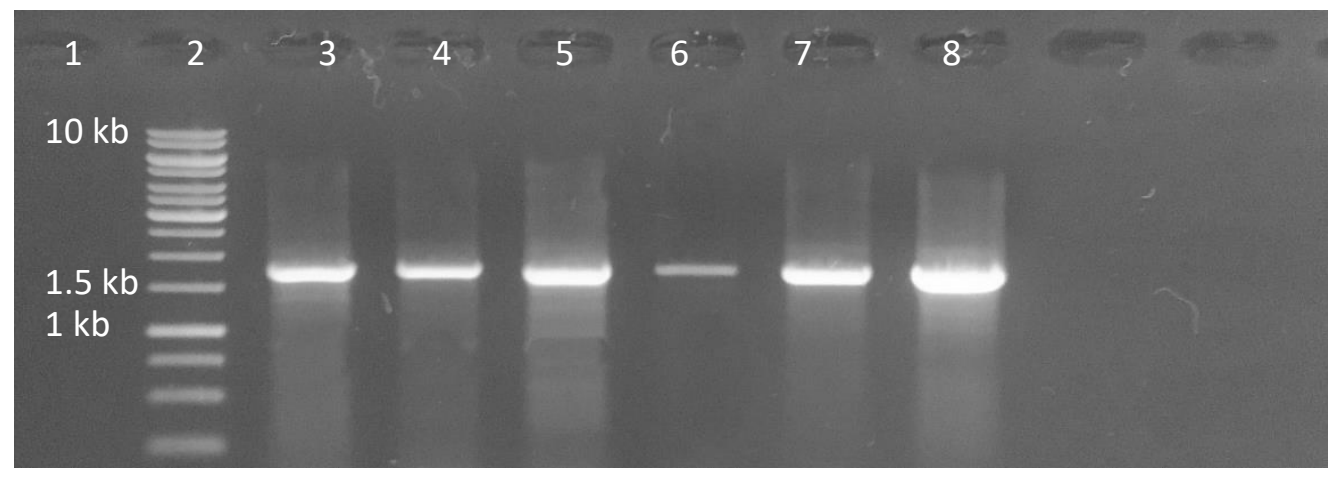

Fig. 2. FcMgv1, FcStuA, and $F c V e A$ genes amplified from F2, F19 isolates.1: negative control, 2: 1kb size marker (Thermo, ABD), 3, 5, 7: from $\mathrm{F} 2$ isolate, 4, 6 and 8: from F19 isolate, 3, 4; 5, 6 and 7, 8 FcMgvl, FcStuA and FcVeA PCR product, respectively.

\section{gDNA Isolation and PCR analysis}

gDNAs were extracted from 7-day-old cultures of the isolates F2, 18F, $12 \mathrm{~F}$ and F19. High quality $\left(\mathrm{A}_{260 / 280}=1.7-\right.$ $1.9)$ and quantity $(1-2.5 \mu \mathrm{g} / \mu \mathrm{L})$ of gDNAs were obtained from $100 \mathrm{mg}$ fresh mycelia.

FcMgv1, FcStuA and FcVeA genes were used in genetic characterizations. 1733, 2001 and 1898bp amplicons were obtained from each isolate (Fig. 2). PCR amplicons purified from agarose gels were checked on agarose gel again. The PCR bands visible on gels (approximately 20-100ng/ $\mu \mathrm{L}$ ) were subjected to sequencing analysis.

\section{Alignment analysis}

Nucleotide sequence data of FcMgv1, FcStuA and $F c V e A$ genes were screened and subjected to BLASTn analysis. The similarity of the sequence data with target associated genes recorded on GenBank (Table 3) was found to be significant. The E-values and maximum bit scores ranged from 0.0 to 0.0 and from 1188 to 3256 , respectively.

The assembled FcMgvl, FcStuA and FcVeA sequences were subjected to ClustalW and NJ topology analysis. The nucleotide sequence data obtained from the three genes were merged and used as a single locus in homology analysis. According to ClustalW analysis minimum bootstrap support value was $89 \%$ (Fig. 3). The minimum and maximum genetic similarity values were ranged from 89 to $99 \%$. According to topology analysis, isolates with the similar LGR values were included in the same sub-cluster and they were genetically closer to each other (Fig. 3). 
Alignment analysis showed that isolates with similar LGR values had the same type of amino acid changes in 430 and 693 points (Fig. 4). HOPE amino acid mutation analysis showed that these mutations occurred as conversion of proline to leucin and glycin to serine could directly affect ligand and substrate binding interactions with proteins coded by the genes used.

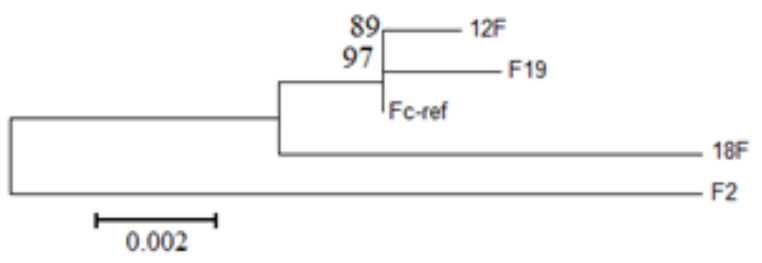

Fig. 3. Maximum Likelihood phylogram of the isolates. Bootstrap support values above $70 \%$ are shown above the branches.

Table 3. BLASTn analysis of three genes aligned in this study.

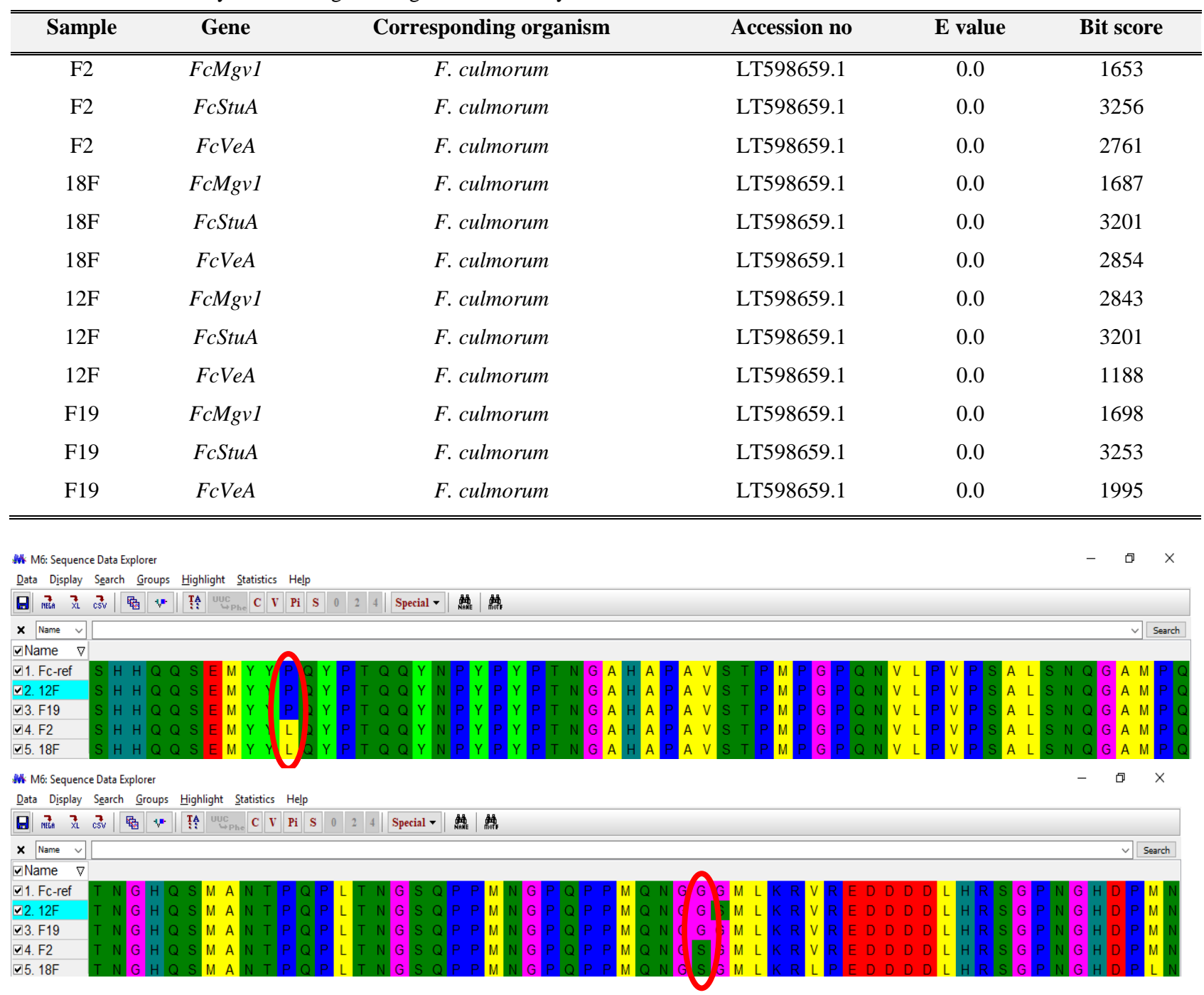

Fig. 4. Phylogeny analysis obtained with MEGA 6.0 software. The boxes within the red circle show the mutations. Fc-ref means the merged nucleotide sequences of $F c M g v 1, F c S t u A$ and $F c V e A$, respectively.

\section{Discussion}

Fusarium head blight and crown rot of cereals are among the fungi-based destructive diseases worldwide (Miedaner et al. 2008, Yli-Mattila et al. 2013, Pasquali \& Migheli 2014). Diagnosis and genetic characterization of causal agents of these diseases form the crucial step in disease management. The comprehensive genotyping strategies would provide useful data and knowledge in order to fight with $F$. culmorum which is major causal agent of head blight and crown rot in many countries. The majority of studies on population structure of $F$. culmorum mainly include the use of molecular marker techniques. These techniques are generally associated with targeting and amplifying unknown or random sites on genomes. These marker strategies have some disadvantageous in usage because they do not allow obtainment of co-dominant markers, the data obtained through these strategies are non-reproducible and they are likely to yield false positive results (Miedaner et al. 2008, Ward et al. 2008). However, multilocus genealogical concordance analysis provides more allele specific and reliable findings about genetic characteristics of fungal 
samples. Moreover, co-dominant markers could be provided via multiloci genotyping. $F$. graminearum species complex members have been successfully identified via genealogical concordance analysis of genes with highly conserved nucleotide sequence data (O'Donnell et al. 2000, Yli-Mattila et al. 2009, Sarver et al. 2011). However, there is no additional usage of these conserved markers for making correlation between genetic diversity and some phenotypic characteristics including radial growth capacity, host type, macroconidium reproduction, chemotype differences or mating type. Yörük \& Sefer (2017) used FgMgv1, FgStuA and $\mathrm{FgVeA}$ genes in order to make association with genetic similarity and chemotype and radial growth rate in F. graminearum. The results obtained from $F g M g v l$, FgStuA and FgVeA sequencing in F. graminearum showed that nucleotide sequence of these genes could be used as a supportive tool for detailed characterization of hemi-biotrophic species. However, there exist no data about detailed analysis of these genes for monophyletic species such as $F$. culmorum, $F$. semitectum, $F$. poae etc. and about amino acids alignments. Also, genotypic diversity and bootstrap support values obtained from this study were relatively close to the results obtained from individuals of $F$. graminearum species complex (O’Donnell et al. 2000, Yli-Mattila et al. 2009, Sarver et al. 2011). It was shown that $M g v 1$, StuA and $V e A$ genotyping could be useful in differentiation of highly divergent individuals of fungal populations. In this study, we used $F c M g v l, F c S t u A$ and $F c V e A$ genes for the first time as a simple gene set for making association between genetic and phenotypic characteristics in. LGR and associated amino acid sequence alterations of $F c M g v 1$, $F c S t u A$ and $F c V e A$ were evaluated for necrotrophic fungus $F$. culmorum for the first time. These three genes could also be used in detailed genetic characterization of phytopathogenic fungi which could lead to devastating diseases worldwide such as F. fujikori (Niren-berg) species complex and $F$. oxysporum (Sacc.) species complex. Aggressiveness, host range and genotypic diversity in members of these species complexes are issues which are not well known. Thus, in addition to

\section{References}

1. Albayrak, G., Yörük, E., Gazdagli, A. \& Sharifnabi, B. 2016. Genetic diversity among Fusarium graminearum and F. culmorum isolates based on ISSR markers. Archieves of Biological Sciences, 68(2): 333-343.

2. Bornet, B. \& Branchard, M. 2001. Nonanchored inter simple sequence repeat (ISSR) Markers: reproducible and specific tools for genome fingerprinting. Plant Molecular Biology Reporter, 19: 209-215.

3. Chung, W.H., Ishii, H., Nishimura, K., Ohshima, M., Iwama, T. \& Yoshimatsu H. 2008. Genetic analysis and PCR-based identification of major Fusarium species causing head blight on wheat in Japan. Journal of General Plant Pathology, 10: 110-118.

4. Desjardins, A.E. \& Proctor, R.H. 2007. Molecular biology of Fusarium mycotoxins, International Journal of Food Microbiology, 119: 47-50. genotyping of $F$. culmorum which is monophyletic phytopathogen, these three genes could be used in genotyping of fungal species complexes. Moreover, these genes could provide additional data for some important characteristics such as chemotype profiles which is still problematic worldwide (Pasquali \& Migheli 2014, Pasquali et al. 2016). These kinds of novel approaches could contribute to disease management of monophyletic and polyphyletic fungi with different chemotypes.

We used, considering the data of LGR analysis, the isolates with relatively low and high in vitro growth capacity in genotyping analysis. Almost all Turkish $F$. culmorum isolates showed a high level of in vitro growth capacity compared to Fusarium spp. isolates subjected to LGR analysis in previous studies. (Chung et al. 2008, Irzykowska et al. 2013). Nucleotide sequence data of $F c M g v 1, F c S t u A$ and $F c V e A$ genes were firstly subjected to detailed BLASTn and multiple nucleotide alignment analysis. Predictably, each nucleotide sequence data showed maximum E-value with corresponding gene located at $F$. culmorum chromosomes deposited on GenBank. Assembled sequences were used in multiple alignment and phylogeny assays. Multiple alignment analysis provided effective results with bootstrap support more than $89 \%$. Maximum likelihood topology analysis showed that isolates with the similar LGR values were coclustered in the same sub-clusters. Moreover, isolates with the similar characteristics showed the same amino acid changes in comparison to isolates with distinct characteristics. Protein modelling analysis showed that the mutations detected in the genes subjected to the multilocus genotyping analysis could lead to alterations in structure and affinity and changes in 3D configurations in the proteins coded by these genes. Our present findings showed that the genes used in this study could be adapted to novel genotyping studies which could be useful in making association of genetic and phenotypic characteristics in Fusarium spp. Different isolates originating from different regions should be used in further studies in order to support the techniques used in the present study.

5. Hou, Z., Xue, C., Peng, Y., Katan, T., Kistler, H.C. \& Xu, J. 2002. A mitogen-activated protein kinase gene (MGV1) in Fusarium graminearum is required for female fertility heterokaryon formation, and plant infection. International Society for Molecular Plant-Microbe Interactions, 11: 1119-1127.

6. Irzykowska, L., Bocianowski, J. \& Baturo-Cieśniewska, A. 2013. Association of mating-type with mycelium growth rate and genetic variability of Fusarium culmorum. Central European Journal of Biology, 8(7): 701-711.

7. Jiang, J., Liu, X., Yin, Y. \& Ma, Z. 2011. Involment of a Velvet protein FgVeA in the regulation of asexual development lipid and seconder metabolisms in virulance in Fusarium graminearum. PLoS ONE, 6(11): e28291.

8. Llorens, A., Hinojo, M.J., Mateo, R., Medina, A., ValleAlgarre, F.M., Gonzalez-Jaen, M.T. \& Jimenez, M. 2006. 
Variability and characterization of mycotoxin producing Fusarium spp. isolates by PCR-RFLP analysis of the IGSrDNA region. Antonie van Leeuwenhoek, 89: 465-478.

9. Miedaner, T., Schilling, A.G. \& Geiger, H.H. 2001. Molecular genetic diversity and variation for aggressiveness in populations of Fusarium graminearum and Fusarium culmorum sampled from wheat fields in different countries. Journal of Phytopathology, 149: 641648.

10. Miedaner, T., Cumagun, C.J.R. \& Chakraborty, S. 2008. Population genetics of three important head blight pathogens Fusarium graminearum, F. pseudograminearum and F. culmorum. Journal of Phytopathology, 156: 129139.

11. Mishra, P.K., Fox, R.T.V. \& Culham, A. 2003. Inter simple sequence repeat and aggressiveness analysis revealed high genetic diversity, recombination and long-range dispersal in Fusarium culmorum. Annals of Applied Biology, 143: 291-301.

12. Nicholson, P., Simpson, D.R., Weston, G., Rezanoor, H.N. \& Lees, A.K. 1998. Detection and quantification of Fusarium culmorum and Fusarium graminearum in cereals using PCR assays. Physiological and Molecular Plant Pathology, 53: 17-37.

13. Niessen, L. 2007. PCR-based diagnosis and quantification of mycotoxin producing fungi. International Journal of Food Microbiology, 119: 38-46.

14. Obanor, F., Erginbas-Orakci, G., Tunali, B., Nicol, J.M. \& Chakraborty, S. 2010. Fusarium culmorum is a single phylogenetic species based on multilocus sequence analysis. Fungal Biology, 114: 753-765.

15. O’Donnell, K., Kistler, H.C., Tacke, B.K. \& Casper, H.H. 2000. Gene genealogies reveal global phylogeographic structure and reproductive isolation among lineages of Fusarium graminearum, the fungus causing wheat scab. Proceedings of the National Academy of Sciences, 97(14): 7905-7910.

16. Pasquali, M., Spanu, F., Scherm, B., Balmas, V., Hoffmann, L., Beyer, M. \& Migheli, Q. 2013. FcStuA from Fusarium culmorum controls wheat foot and root rot in a toxin dispensable manner. PLOS ONE, 8(2): e57429.

17. Pasquali, M. \& Migheli, Q. 2014. Genetic approaches to chemotype determination in type B-trichothecene producing Fusaria. International Journal of Food Microbiology, 189: 164-182.

18. Pasquali, M., Pasquali, M., Beyer, M., Logrieco, A., Audenaert, K., Balmas, V., Basler, R., Boutigny, A.L., Chrpová, J., Czembor, E., Gagkaeva, T., González-Jaén, M.T., Hofgaard, I.S., Köycü, N.D., Hoffmann, L., Lević, J., Marín, P., Miedaner, T., Migheli, Q., Moretti, A., Müller, M.E., Munaut, F., Parikka, P., Pallez-Barthel, M., Piec, J., Scauflaire, J., Scherm, B., Stanković, S., Thrane, U., Uhlig, S., Vanheule, A., Yli-Mattila, T. \& Vogelgsang, S. 2016. A European Database of Fusarium graminearum and $F$. culmorum Trichothecene Genotypes. Frontiers in Microbiology, 7: e406.
19. Przemieniecki, S.W., Kurowski, T.P. \& Korzekwa, K. 2014. Chemotypes and geographic distribution of the Fusarium graminearum species complex. Environmental Biotechnology, 10(2): 45-54.

20. Rozen, S. \& Skaletsky, H. 2000. Primer3 on the WWW for general users and for biologist programmers. Methods in Molecular Biology, 132: 365-386.

21. Sarver, B.A.J., Ward, T.J., Gale, L.R., Broz, K., Kistler, H.C., Aoki, T., Nicholson, P., Carter, J. \& O'Donnell, K. 2011. Novel fusarium head blight pathogens from Nepal and Louisiana revealed by multilocus genealogical concordance. Fungal Genetics and Biology, 48:1096-1107.

22. Tamura, K., Stecher, G., Peterson, D., Filipski, A. \& Kumar, S. 2013. MEGA6: Molecular Evolutionary Genetics Analysis Version 6.0. Molecular Biology and Evolution, 30(12): 2725-2529.

23. van der Lee, T., Zhang, H., van Diepeningen, A. \& Waalwijk, C. 2015. Biogeography of Fusarium graminearum species complex and chemotypes: a review. Food Additives and Contaminants: Part A, 32(4): 453-460.

24. Ward, T.J., Clear, R.M., Rooney, A.P., O’Donnell, K., Gaba, D., Patrick, S., Starkey, D.E., Gilbert, J., Geiser, D.M. \& Nowicki, T.W. 2008. An adaptive evolutionary shift in Fusarium head blight pathogen populations is driving the rapid spread of more toxigenic Fusarium graminearum in North America. Fungal Genetics and Biology, 45: 473-484.

25. Williams, J.G.K., Kubelik, A.R., Livak, K.J., Rafalski, J.A. \& Tingey, S.V. 1990. DNA polymorphisms amplified by arbitrary primers are useful as genetic markers. Nucleic Asid Research, 18(22): 6531-6535.

26. Yli-Mattila, T., Gagkaeva, T., Ward, T.J., Aoki, T., Kıstler, H.C. \& O'Donnell, K. 2009. A Novel Asian clade within the Fusarium graminearum species complex includes a newly discovered cereal head blight pathogen from the Russian Far East. Mycologia, 101: 841-852.

27. Yli-Mattila, T., Hietaniemiv, R., Hussientcarlobos-Lopez, A. \& Cumagun, C.Jr. 2013. Molecular quantification and genetic diversity of toxigenic Fusarium species in Northern Europe as compared to those in Southern Europe. Microorganisms, 1: 162-174.

28. Yörük, E., Tunali, B., Kansu, B., Ölmez, F., Uz, G., Zümrüt, I.M., Sarıkaya, A. \& Meyva, G. 2016. Characterization of high-level deoxynivalenol producer Fusarium graminearum and $F$. culmorum isolates caused head blight and crown rot diseases in Turkey. Journal of Plant Diseases and Protection, 123: 177-186.

29. Yörük, E. \& Sefer, Ö. 2017. Polymorphisms in FgMgv1, FgStuA and FgVeA genes associated with growth of Fusarium graminearum. Pp. 358-366. In: Arapgirlioğlu, H., Atık, A., Elliott, R.L. \& Turgeon E. (eds), Researches on science and art in 21st century Turkey, Gece Kitaplığ1, Ankara Volume 1, 364 pp. 
